Both the author and the editors of the Nero Naturalist are to be congratulated on a considerable contribution to the literature of British mammals, which also provides an authoritative refutation of many current myths about squirrels. There are thirty-two excellent black and white photographs, and a number of interesting and informative maps.

R. S. R. F.

Winged Thundendolt. By G. D. Adams.

Constable and Co., Ltd. 15s.

This review has two authors, one thirteen years old, the other considerably older. 'The junior reviewer writes "This is a very exciting book. I didn't know anything about peregrines before, and now I do ". The senior reviewer feels that his collengue has made a very fair comment. The book does give a vivid sketch of the wild and wandering life of the peregrine and admirably stresses the tremendous distances in the daily and yearly range of these falcons.

The manner and style is reminiscent of that of Mr. Henry Williamson. Indeed, the description of porpoises and grampus at the mouth of an estuary is so like a passage in "Salar the Salmon " as to suggest an essay in pastiche, if not in précis.

There is a rather unfortunate "howler" on the first page, where it is stated that the albumen of the egg differentiates into the young bird! And is $\mathrm{Mr}$. Adams correct in making his peregrine breed in the first year? Mr. J. Walpole-Bond, in Ficld-studies of some raver British Birds says that this species does not breed until the second year.

P. T. II.

P. I. T. II.

\title{
SHORTER NOTICE
}

Uganda National. Parks Findiook, 1954. Published by the Trustees of the Ugandn Nationnl Parks. Price 5s., from Uganda East Afriean Office, Grand Buildings, 'Trafalgar Squarc, W.C. 2.

In addition to the list of animals and plants usually found in guide books, this one contains a very readable introduction to the natural history of the Uganda National Parks. There are chapters also on the geology, geography, and history of the parks.

Scientific information is kept to a minimum for, as the Director rightly says, all such information can be found in reference libraries. Though $\Omega$ mnp of Uganda is included with the guide book it is merely a rond map and gives very little iden of the geography of the region. 